\title{
WEB 2.0 BASED AVT
}

\author{
Alvin Taufik* and Vesalia Widawati \\ English Language and Culture Department, Bunda Mulia University
}

Received on 29 March 2018 / Approved on 16 April 2018

\begin{abstract}
The advances in information and communication technology (ICT) has created an opportunity for better interaction and collaboration. In turns, these web 2.0 technologies have encouraged creativity and participation from its users. One of the areas impacted by this is in language teaching and learning. More researchers are using these web 2.0 technologies in their teaching. This research focuses on the core concept of web 2.0 in the most popular video-based social media that is Youtube. The researcher will investigate the features and elements embedded ad available in Youtube which corresponds to the core concept of web 2.0 of collaboration and interactivity. Furthermore, the researcher will devise methods to integrate such concept in language learning, more specifically, on audiovisual translation. The final results are expected to lay the foundations of further interactivity and collaboration in said subjects, and other subjects in which there are potentials to integrate other web 2.0 technologies.
\end{abstract}

Keywords: web 2.0 technologies, Youtube, interactive, collaboration

\begin{abstract}
ABSTRAK
Kemajuan teknologi informasi dan komunikasi (TIK) telah menciptakan peluang untuk interaksi dan kolaborasi yang lebih baik. Teknologi web 2.0 ini telah mendorong kreativitas dan partisipasi dari para penggunanya. Salah satu bidang yang terkena dampak ini adalah pengajaran dan pembelajaran bahasa. Lebih banyak peneliti menggunakan teknologi web 2.0 ini dalam pengajaran mereka. Penelitian ini berfokus pada konsep inti web 2.0 di media sosial berbasis video paling populer yaitu Youtube. Peneliti akan menyelidiki fitur dan elemen yang disematkan dan tersedia di Youtube yang sesuai dengan konsep inti kolaborasi dan interaktivitas web 2.0. Selanjutnya, peneliti akan menyusun metode untuk mengintegrasikan konsep tersebut dalam pembelajaran bahasa, lebih khusus lagi, pada studi penerjemahan audiovisual. Hasil akhir diharapkan untuk meletakkan dasar interaktivitas dan kolaborasi lebih lanjut dalam mata pelajaran tersebut, dan mata pelajaran lain di mana ada potensi untuk mengintegrasikan teknologi web 2.0 lainnya.
\end{abstract}

Kata Kunci: Teknologi Web 2.0, Youtube, Interaktif, Kolaborasi

\section{INTRODUCTION}

\section{Background of Study}

One of the most prolific examples of web 2.0 technologies are social media websites. People are getting more and more attached to social media these days. The people's needs or desires to be acknowledged or recognized has been prompted to be the cause of the phenomenon. Some also attribute the rise of social media to the different ways people choose to express themselves. Social media provides various environment for people to express themselves; ranging from only in the form of characters into videos. The latter has now become so omnipotent.

There are many video-based social media channels in the world wide web. Whatman (2017) states that there are four most used video-based social media available on the web today; Periscope, Vine, Snapchat, and Youtube. Periscope and Vine are both owned by Twitter. Periscope focuses primarily on live streaming while vine is a very short movie

*Author(s) Correspondence:

E-mail: ataufik@bundamulia.ac.id 
sharing site. Videos shared on vine are only six second long. Snapchat is based on a series of pictures which make stories. The video itself is only 10 second long. So, while its rapid growth is good for marketing, but for other potential additional features, it just won't cut it.

That leaves the researcher with Youtube. First, let us take a look on a statistics. Hopefully, this explanation will provide a very reasonable initial impression on why this site is perfect for many different situations, including teaching of foreign language.

First of all, to the best knowledge of the researcher, the videos in Youtube can have a very long duration. In his initial observation, the researcher has found videos with duration from seconds to hours. Secondly, people around the world are watching one billion hours of video everyday. This makes Youtube the most watched video-based website or social media in the world. With more views, it generates more videos made. Thus, it leads to an endless lineups of video which can be used for many different functions. It also signifies the people's degree of interest toward the site. Some of the people who are interested might be our potential or current students. So, by using Youtube for specific purposes, it also means keeping up with or giving what the audience really desires.

The statistics also signal for further interactivity and collaboration from the audience. Youtube has done just that. These features and elements which have enabled further interaction and collaboration will be the focus on the investigation in this research. In addition, this research also seeks its potential for language learning.

\section{Statement of Problem and Research Questions}

In integrating the web 2.0 techologies in language learning or teaching, there are two specific questions which need to be addressed. Firstly, the researcher needs to investigate the elements and features of Youtube which have the potential of increasing connectivity, interaction, and collaboration. The second is the researcher also needs to devise a way for him to integrate the findings in language teaching and learning.

\section{Research Objectives and Significance}

This research is aimed at integrating Web 2.0 technology features into language learning, especially in the teching and learning of Audiovisual Translation. This research is significant in providing valuable input in the form of material or resources collection. In addition, this research is also significant in providing alternative instructions in language classroom. Finally, this research is useful because it caters to the need of the digital natives.

\section{THEORETICAL FRAMEWORK}

\section{Web 2.0: What is it?}

This terminology was first coined by Tim O'Reilly and Dale Dougherty in a conference brainstorming session in Fall 2001. Since its coinage, many have still debated on whether it is a terminology worth recognizing, or just a media buzz. The followings are some examples of the difference between web 1.0 and web 2.0 (O'Reilly, 2005):

\begin{tabular}{ll} 
Web 1.0 & \multicolumn{1}{c}{ Web 2.0 } \\
DoubleClick & $\rightarrow$ Google AdSense \\
Ofoto & $\rightarrow$ Flickr \\
Akamai & $\rightarrow$ BitTorrent \\
mp3.com & $\rightarrow$ Napster \\
Britannica Online & $\rightarrow$ Wikipedia \\
personal websites & $\rightarrow$ blogging \\
evite & $\rightarrow$ upcoming.org \\
& $\quad$ and EVDB \\
domain name speculation & $\rightarrow$ search engine \\
page views & $\quad$ optimization \\
screen scraping & $\rightarrow$ cost per click \\
publishing & $\rightarrow$ web services \\
content management & $\rightarrow$ participation \\
systems & $\rightarrow$ wikis \\
directories (taxonomy) & $\rightarrow$ tagging \\
stickiness & ("folksonomy")
\end{tabular}

*Author(s) Correspondence:

E-mail: ataufik@bundamulia.ac.id 
The arrows next to the words show that there has been a movement from the old system into new, with an emphasize mostly on interaction and collaboration. Take for example, Britannica Online, which is shown to have been outdone by Wikipedia. In Britannica Online, user can only views the content of the web, while in Wiki, as it is commonly recognized, user can actually contribute to the site by providing better reference for the specific concept, for example.

At its core, web 2.0 treats web as a platform. In it, the user has control over his or her own data. Its core competencies include the notion that it offers services instead of packaged softwares, architecture of participation, cost effective scalability, remixable data source and transformation, above-a-single-device level software, and collective intelligence.

One company which follows the previously stated feature of web 2.0 is Google. It is a known fact that Youtube was bought by Google in the 2000s. Anyway, as are the core competencies of web 2.0, Google started as applications; it was never sold or packaged. It provides continuous improvement.

In relation to this, it is mentioned that the system is going to get better the more it is used. This, in my opininion, is a very important aspects in promoting collaboration and participation. One example of this is Google Translate in which it gets better the more you used, and contribute to its improvement. The previous statement also contains two of the key concepts of web 2.0: It gets better the more you use it and contribution of intelligence.

When talking about participation and contribution, users probably will not do it if they are asked explicitly. Therefore, their participation needs to be architectured; hence the name 'architecture of participation'. One suggestion for this is to make it as a default. It then regulates that any users who are going to use the application have to contribute to the system.

Other features of web 2.0 which are worth mentioning is on the user interface and multiple device operation. As stated previously, one of the key concepts of web 2.0 is user contribution. Therefore, web 2.0 applications or companies must offer lightweight user interface to accomodate for such interaction. In addition, the contribution which can be given by the users should not be limited to PCs, especially in this mobile era. Thus, when designing the programs or applications, one needs to accomodate its uses in handheld device as well.

Finally, to accomodate all the features of web 2.0 as mentioned above, a database management is needed. This data management needs to accomodate even the smallest of contribution. Such data management system is referred to as the long tail, since it does not only manage the head (i.e. company based database) but also the tails (making users become the individual server which contributes to the web service).

\section{Youtube for Educational Purposes}

Having seen that the company behind Youtube is a poster child for web 2.0 technology, is it safe to assume it is the perfect 2.0 tool? Ths research is aimed to investigate that notion. In this part of the paper however, only the explanation of Youtube in detail, and on past research of Youtube uses for educational purposes.

Since the features of youtube is the focus of the research, so, in this paper, only the explanation on the features will be explained. At first, Youtube is using Adobe Flash player in its playback features, however in 2015, it announced that it uses HTML5 as its default playback method. This enables supported browser to play the video without Flash Player or other Plug-ins.

In terms of uploads, all users are able to upload up to 15 minutes video. Some users who have been used to the community guidelines can upload a video of up to 12 hours. Captions are provided by speech recognition technology. Although it is not perfect, Youtube has provided options to make it better.

Most videos allow users to comment on it. In the early stages, however, it was vastly criticized for its often blatant stupidity

\footnotetext{
*Author(s) Correspondence:

E-mail: ataufik@bundamulia.ac.id
} 
and aggressiveness. In 2016, a scheme was introduced to allow users to organize the comments made on their videos. This scheme uses algorhythm that detects negative comments. This scheme also allows other users to moderate their comments.

Many research have been dedicated on the educational benefits of Youtube in the classroom. A huge majority of the research has pointed out the significance of Youtube in providing teaching resources (Jones \& Cuthrell, 2011; Brunner, 2013) Brunner has actually made a lesson plan for it. Terantino's column (2011) has elaborated on the integration of the channel into his teaching. Moreover, he also provided detailed desciption of the digital natives and educational needs.

Digital natives refer to people who grow up using digital technology. One important aspects of these society is the way they interact. What was one a face to face interaction has been replaced by social medias, text messages, and video games. With respect to this pattern of socialization, there should be a modification of instructions and activities. The following are Prensky's definitions of educational needs of the digital natives (2011):

a. To receive information at twitch speed

b. To be able to multi-task

c. To have hands-on activities

d. To have graphics before text

e. To have random access to information

f. To be networked socially

g. To play games rather than do serious work

h. To have frequent rewards

Terantino further explained some common uses of Youtube in language classroom. One of them is in providing linguistics and cultural content of foreign language. With a video, some linguistics and cultural instructions which were otherwise comprehensible in written form, is made clearer because, often, they provide spoken sample, spoken and wriiten practices, and alternate viewpoints.

Youtube as a videosharing site, also enables students to create their own target language situations. For example, students who are learning grammar can upload a video of them teaching a specific grammar point. Motivation and creativity is built with these activities.

In terms of collaboration, Youtube also offers several project that can be done collaboratively. Most of these products are in the form of news projects and short skits on target language. In addition, Youtube also allows its users to provide feedback through text postings or video postings. This way students can interact and receive real life feedback from people around the world.

\section{RESEARCH METHODOLOGY}

Prior to setting the methods and methodology which will be used in the research, the researcher believes it is imperative to talk about translation studies and its philosophical standing.

Matthews and Ross (2010) has mapped the general research ontology; objectivism, constructivism, and realism, and their epistemology; positivism, interpretism, and realism.

Objectivism with its positivism epistemology looks at social world as a separate measureable object that exist without the interference of its social actor, or human. This is often related to the natural science, hence its quantitative approach. Constructivism, with its interpretism epistemology looks at social world as an entity in which its social actor plays a huge role in shaping it. Qualitative approach is often related with these. Realism, on the other hans, is both an ontology and epistemology. It believes that certain social world can exist without the influence of its social actor, yet also believe that the social world is shaped by an invisible existence which effects might provide the existence of a structure and mechanism. Mixed approach is often used in this category.

Specifying the matters even further, there are specific research terms that are going to be used exclusively in this research which are mainly derived from Silverman (2006, p.

\footnotetext{
*Author(s) Correspondence:

E-mail: ataufik@bundamulia.ac.id
} 
13) and Matthews and Ross (2010, p. 34 \& 112) respectively. Model is a representation of reality. In a certain model, a framework is used to view and gather knowledge in said 'reality'. There are several concepts which can be derived from the model. Those concepts are categorized into a theory. Having figures out the model, concept, framework, and theory, the researcher can now decide on the methodology, which is basically an approach to study the phenomenon. The qualitative, quantitative, and mixed approach mentioned earlier is specified as methodology. In said methodology there are specific research techniques to be used which is often referred to as the methods. Finally, to apply the method, a number of tools are needed. Deriving from the explanations stated earlier, this research methodology can be smmarized into the followings;

This research is constructivism in ontology and interpretism in its epistemology. It realizes that the social world is constructed by its social agents. This is closely related to the concept of web 2.0 which emphasizes participation. The model in this research is the Youtube as the social media and its constructive society. Several theories on participatory learning structured its framework. There are also theories on audiovisual translation, especially on using subtitles or captions. The methodology often used in this type of research is qualitative methodology. The technique which will be used in this research is observation of the students' work and digital interviews. Finally, the tools which will be used in this research are the Youtube itself and some additional caption creator softwares.

The research was done initially by observing the elements which are related to the characteristics of web 2.0 technology in Youtube. After that, in answering the second research question, the researcher, who doubled as the lecturer, created a video to be transcribed automatically. After that, the students were asked to contribute their editing to the video. Then, the contribution were reviewed. After that, the students were asked to fill in the questionnaire prepared by the researchers. After the results had been collected, they were sorted and tabulated. The sorting and tabulation became the basis of further analysis. The result of the sorting and tabulation was presented in the form of bar chart. This was the best way to present data from Likert scale, especially since the focus was on the frequency of the data.

\section{FINDINGS AND DISCUSSION}

\section{Findings}

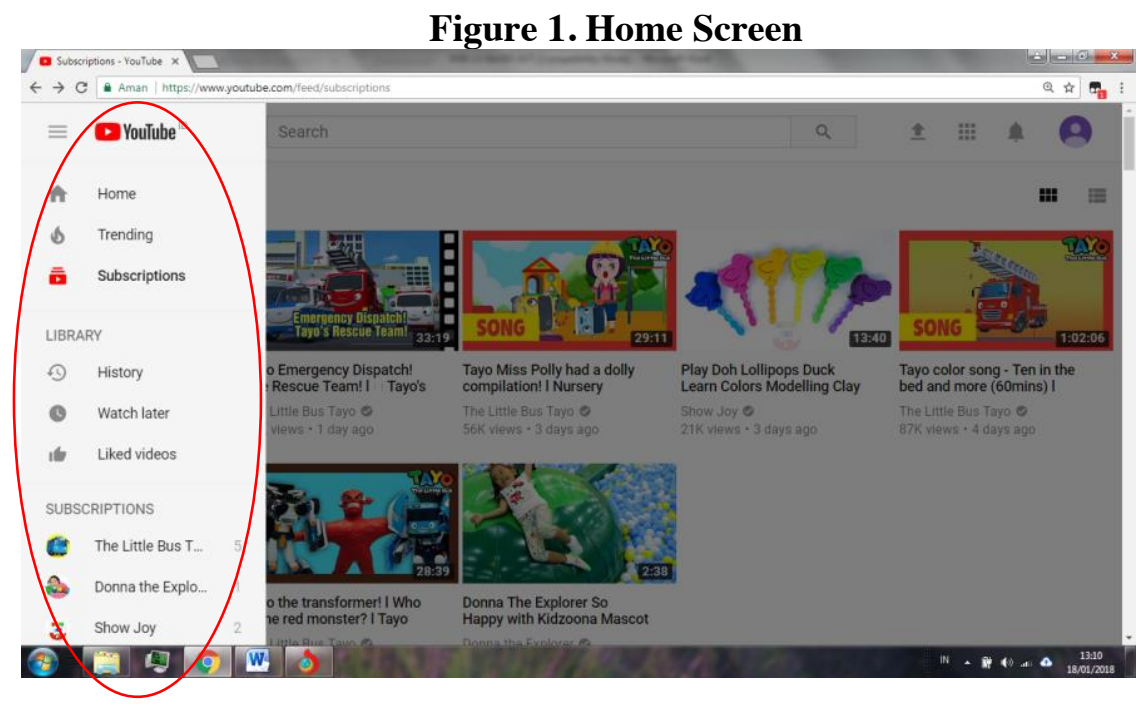

*Author(s) Correspondence:

E-mail: ataufik@bundamulia.ac.id 


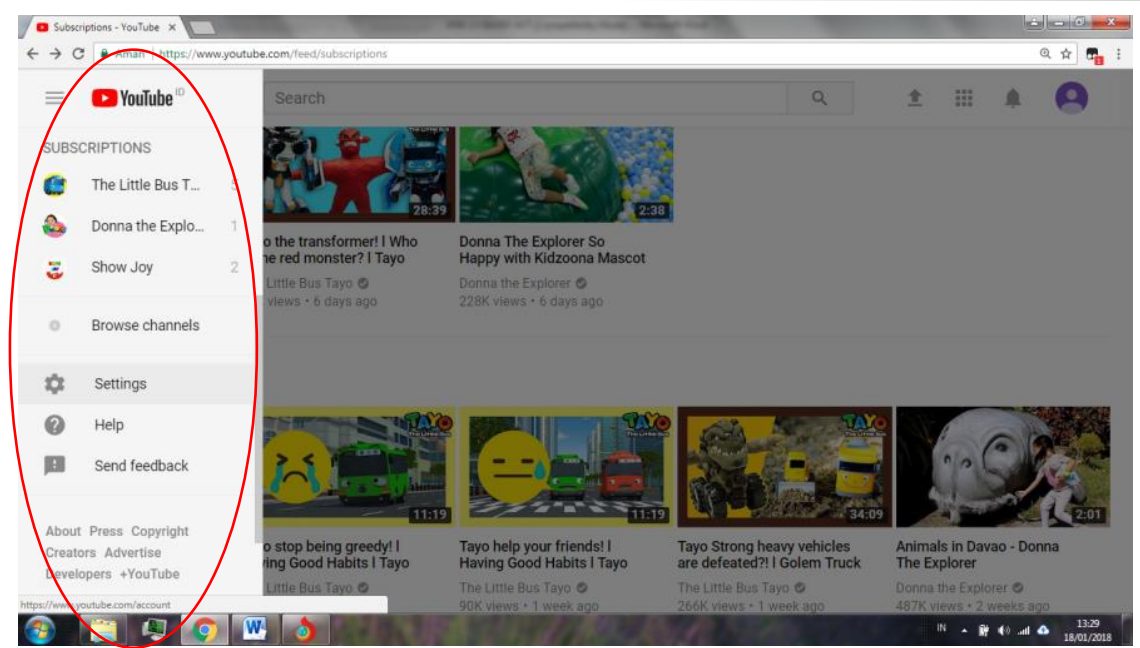

The followings are what has been found in this research in relation to Youtube compatibility with Web 2.0 features. First, let us take a look at the home screen in Figure 1. In this home screen (as highlighted by a circle) , there are lists based on certain categories. The first list is based on Home category. In this category there is the home screen page link, which shows our preferences of Youtube videos; the Trending page link, which features the videos which are trending in the world; and the Subscription page link which shows what videos we are subscribing to at the moment.

In the second category, there are lists based on the category of library. The first page link is the History. By clicking this link, users will be taken to the list of videos which have been watched recently. The next link is for the Watch Later page. This page is filled with videos that viewers have boomarked to be watched later on. The last link in this category is for the Liked Videos page. Like its name says, this is a page of videos that the viewers liked.

The third category is about the videos that the viewers have subscribed. The difference between this category with one of the page in the home screen is that these links will directly connect with the videos which the viewers have subscribed to. The fourth category is the Browse Channel link. When viewers click this link, they will be directed to the channels which are based on specific categories such as Popular on Youtube, Music, Creator on the Rise, Comedy, Film and Entertainment, and others.

The next link is the Account Setting page link. In this, there are more categories. The first category is the Account Overview. By clicking this category, viewers will be taken to a page which shows the overview of the viewers account, and additional features. In the additional features, there are links for viewing additional features and Create a New Channel. Clicking View Additional Features will take viewer to one of the category under the Creator Studio category, so it will not be discussed here. The Create a New Channel enables viewer to create a new channel based on new categories.

The second category is the Connected Account. In this category, viewers can connect their google accounts with other accounts used for other social media such as Twitter, Facebook, etc. Viewers can also share their public activity in the Youtube in this category.

The next link will connect viewers to the Privacy setting. As the name suggests, it will set the privacy of different elements of the viewers' account. Some sub-link of the page includes the privacy setting of your liked and subscribed videos, activity feeds, and ads preferences. After that, there is the Notification link. In this, as the name suggests, it notifies viewers on any videos that they are subscribing to, and the comments on the

*Author(s) Correspondence:

E-mail: ataufik@bundamulia.ac.id 
viewers' channel, or viewers' comments on other viewers' channel.

Next, on the Playback setting, there are options on whether viewers want to turn on the annotation and captions. On the last link, viewers are given options to enable Youtube videos to be played on their television sets.

The previous are the set-ups which are available on any viewers' window or interface.
The followings will observe the 'individualized' page. To operate that, user/s (hereinafter, the word "viewer/s" will be replaced with "user/s") need to click on the upper right part of their opened window/s. On it, user/s need to click an option titled 'Creator Studio' to start personalizing their Youtube experience. The following is a figure on said feature.

\section{Figure 2. Creator Studio}

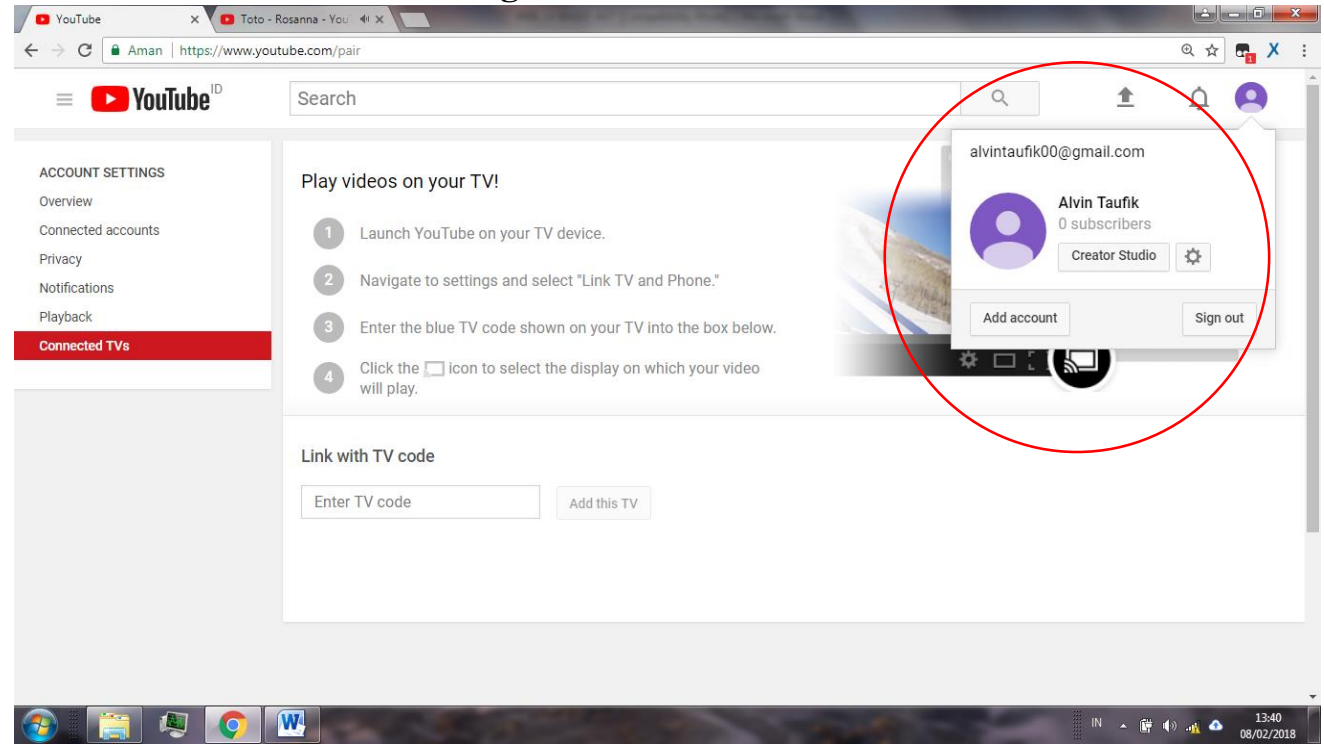

Once it is clicked, user/s will be shown the following page.

Figure 3. Creator Studio - Content

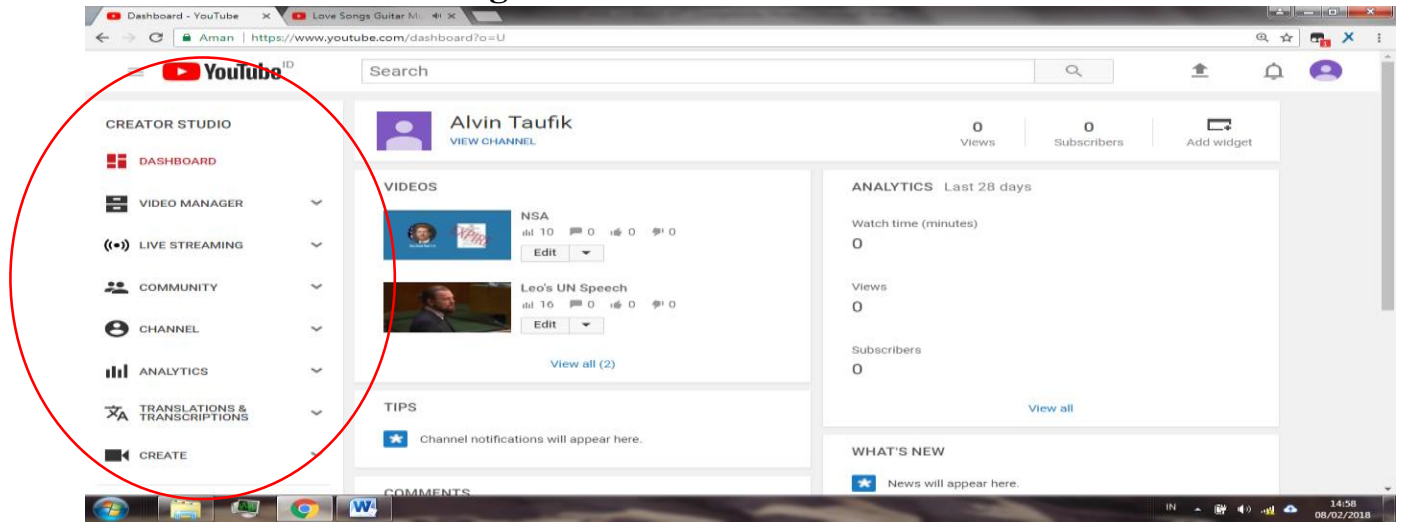

*Author(s) Correspondence:

E-mail: ataufik@bundamulia.ac.id 
On the first link, Dashboard, user/s can see the video/s that they have uploaded and the comments for it/them. It will also take users to the analytics of the video/s.

On the second link, the Video Manager, user/s are given the options to edit their video/s. The user/s can edit the setting of the video/s, which includes the language of the video and even its translation. User/s can also change the privacy setting by choosing one of the four: Public, Unlisted, Private, Scheduled. In this research, students are asked to set it on the Private setting to avoid any violation to copyrights.

User/s can also set up public comments and ratings for the video. In addition, they can also set age restrictions and community contribution. The Enhancement link helps with the picture quality, while Audio options allows user/s to provide music for the video/s.

The End-Screen and Annotation link provides end-screen elements such as call to subscribe, and promotions for the video/s which we have created. Obviously, this is intended for user/s who wishes to monetize their video/s.

The next link is also intended for promotional purposes; it is called Cards. With it, user/s can promote their video/s and channel/s to viewer/s while they are watching the user/s' video/s. They can also conduct a poll on what to be shown on the next video/s, for example.

The next link is the most important link in the teaching of AVT using Youtube since it allows user/s to create ClosedCaptions or Subtitles. The caption which is provided here is the Closed Caption (CC). Closed Caption refers to captions which can be turned on or off whenever the viewer/s wants. The caption and/or subtitle can be both created by the user/s or automatically generated by Youtube. In addition, user/s can also have the community for its contribution in creating the subtitles or captions. The following shows the linked-window.

Figure 4. Closed Caption and/or Subtitle

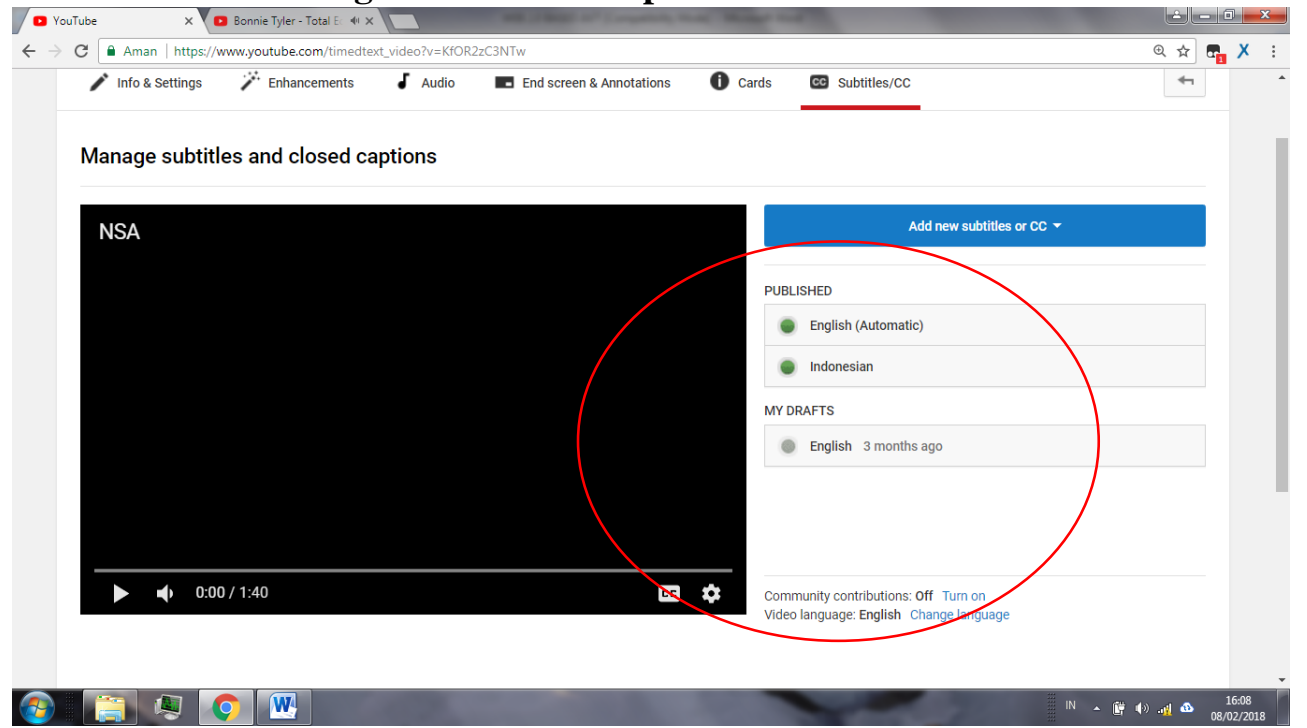

Still on the Video Manager link, user/s can access the playlist link. In it they can create a playlist of the video/s that they want to watch.
Next link is about streaming. In this link, user/s can stream their video game playing or videos. They can even do it live, or they can record it and stream it at scheduled

*Author(s) Correspondence:

E-mail: ataufik@bundamulia.ac.id 
time. There is also a privacy setting here. There are also four options for the privacy.

In the Community setting, user/s have the option to setup the comments for their video, messages, and subscribers. In addition, on the fourth link, there is an option to setup the community. In it, user/s can appoint moderators, approve users, setup hidden users, and even block words, comments, and links which are potentially harmful and/or offensive. In the next link, the Credit, it shows the video/s in which user/s have been credited with.

Next link is the Channel. In it, user/s can view the copyright status of their uploaded video/s, warnings on said copyright, especially if there are violations, the settings for video uploads, video monetizing, live streaming and its tags, private video, longer video/s, custom thumbnail, external annotation, chats, custom URLs, appeals on the warnings, and sponsorships. In it, user/s can also give watermarks for their video to avoid copyright violations. User's can also set the advertisement to be shown with their video.

In the Analytics section, user/s can view the statistics for their uploaded video/s or activities in Youtube in general. This feature is very useful for research purposes.

Another feature which might be useful in promoting language learning is the Translation and Transcription link. Below is the ilustration for it.

Figure 5. Translation and Transcription

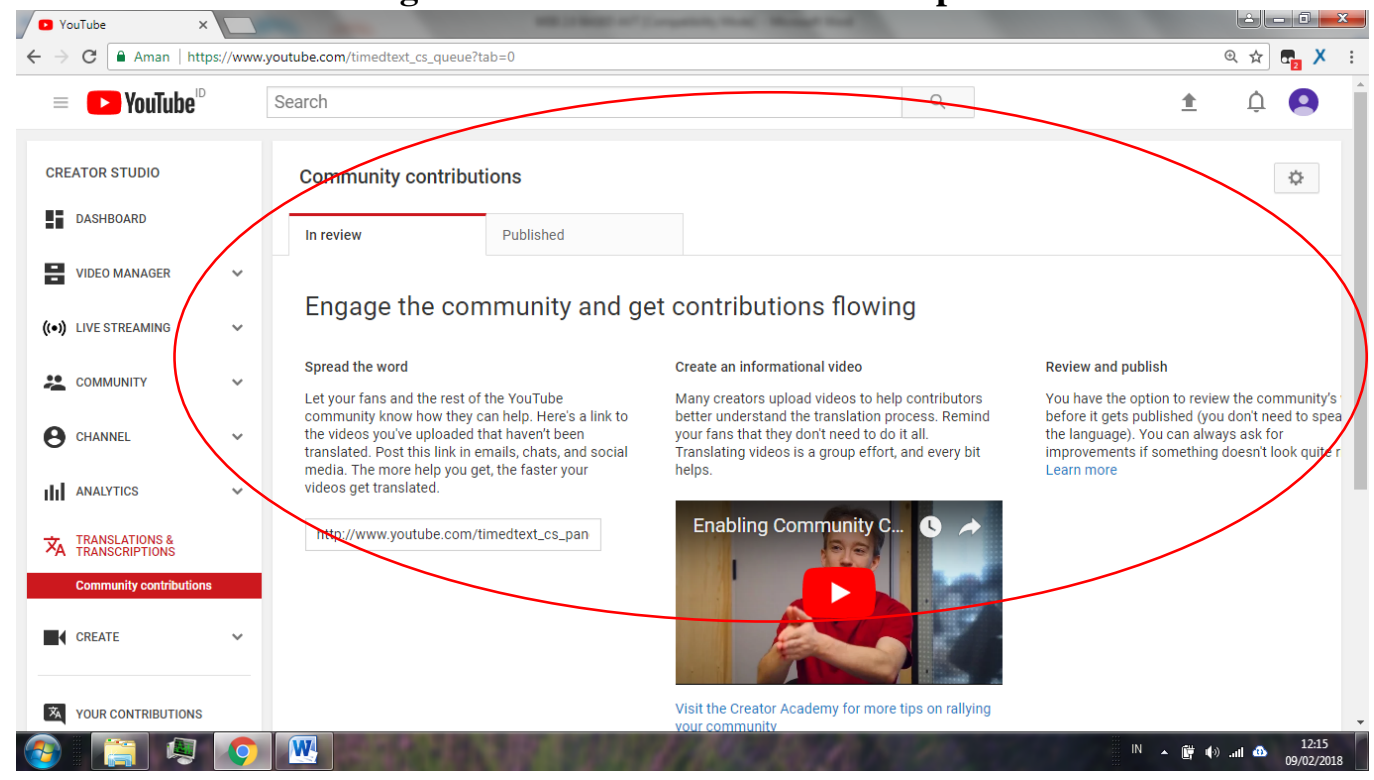

In this link, user/s can set the contribution that can be made by the community. They can also create assistance video to let the community know how to contribute to the video/s. Furthermore, you can also review the contribution before publishing it. This is, in my opinion, a very valuable piece of technology which can be used to teach. In addition, this link is divided into two sections; one is the section to see the reviewed contribution, and the other to see the published contribution.

In the Create section, user/s can create their own music and sound effects. They can browse them from the internet, or upload a new one. They can also use the pre-existing music and sound effects. Finally, in the Contribution link, user/s can see the contribution that they have made to the community.

*Author(s) Correspondence:

E-mail: ataufik@bundamulia.ac.id 
Having seen the features offered by Youtube, it is safe to say that Youtube is indeed a web 2.0 technology. This can be seen from the matching elements it has with web 2.0 characteristics. The details of the matching elements can be seen in the table below.

Table 1. Similarity in Elements

\begin{tabular}{|c|c|}
\hline Youtube & Web 2.0 \\
\hline $\begin{array}{l}\text { Users can modify their videos in } \\
\text { any way they like }\end{array}$ & $\begin{array}{c}\text { It treats the web as a platform, users } \\
\text { can modify their own data }\end{array}$ \\
\hline- & It gets better the more you use it \\
\hline $\begin{array}{l}\text { The Community Contribution } \\
\text { allows for a better transcription and/or } \\
\text { translation. The Translation and } \\
\text { Transcription link allows user to review } \\
\text { and publish selected materials. }\end{array}$ & $\begin{array}{c}\text { Collaboration of Intelligence and } \\
\text { Architectured Participation }\end{array}$ \\
\hline $\begin{array}{l}\text { User/s are one click away from } \\
\text { creating transcription or translation, } \\
\text { allowing community contribution, and } \\
\text { synchronizing the timing of the } \\
\text { transcription and/or translation }\end{array}$ & Friendly user interface \\
\hline $\begin{array}{l}\text { User/s can create and modified their } \\
\text { video on PC, Tablet, or even cellphone }\end{array}$ & Not limited to a single device \\
\hline $\begin{array}{l}\text { As previously mentioned, most } \\
\text { features are personalized. Thus, user/s } \\
\text { serve as personal database managers } \\
\text { which contribute to the web service }\end{array}$ & Personalized database management \\
\hline
\end{tabular}

\section{Possible Uses of Youtube in Language Learning}

Since the purpose of the whole research ist outilize Youtube as a tool to assist in language learning, the researcher is going to observe the platform as the user. Because of that, only the feature which is intended for the user will be the focus of the analysis. The feature which might be useful in language learning, especially in the teaching and learning of Audiovisual Translation is the Closed Caption and Translation creation feature.

One of the main problems in Audiovisual Translation class is creating the transcription. With a feature embedded in the platform, now, students and teachers alike can get an automated caption or translation in a matter of minutes (especially for short instructional videos). This will definitely eliminate the time needed by the students or the teachers to provide transcription as the main element of the teaching (or in a case of translation, a base for the translation).

In addition, students and teachers alike can use the Community Contribution feature to interact online. Teacher or student can create a community within Youtube and turn off the contribution setting. Thus, it allows the students to create or edit or comment on other students' video just like when they are giving suggestions when they do this inside a classroom. An additional advantage is students do not have to be afraid of not being able to contribute due to their nervousness because everything is online; they only need to type in their contribution at their most convenient time.

In addition, by creating the community, they do not have to be wary of Youtube's copyright policy. By setting the video setting in Private, students can still do the necessary editing for the videos shared online in the community. In terms of

*Author(s) Correspondence:

E-mail: ataufik@bundamulia.ac.id 
architectured participation, teachers can review any comments and/or contributions made for the community. However, in this research, the researchers are going to use authentic materials to acquire the responses of the students.

\section{Questionnaire Results}

In its application, the lecturer asks the students to use Youtube in their language learning. They are asked to edit the autogenerate transcription. After that they are asked to fill in the adapted questionnaire sent to their emails. The followings are the link of the experimental video and opinions of the students after using Youtube.

Links:

www.youtube.com/watch? $=\mathrm{Gv}$ oZ3-Fnls

To edit the transcription, they need to go to the Youtube channel and click setting icon on the video, click subtitle or $c c$ tab and click add subtitle or cc. Once they have done that, the following screen will appear (Figure $6)$.

Figure 6. Community Editing Screen

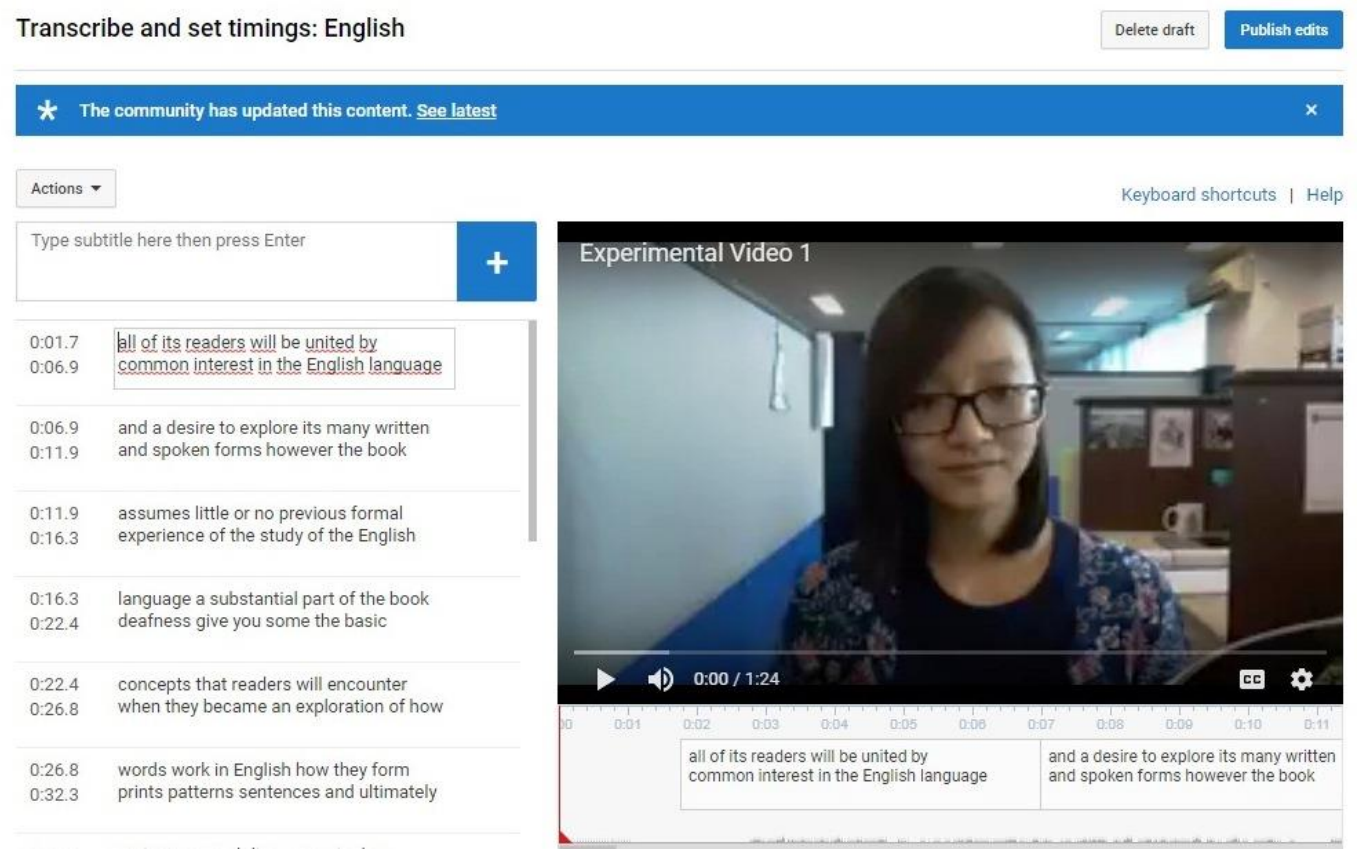

Once the students have finished editing the transcription process. It still need to be reviewed by the administrator, which is in this case, the translator. There will be an email from Youtube notifying that the community has made contribution to your automatically generated video (Figure 7). After the review, the admin has the chance to publish it.

*Author(s) Correspondence:

E-mail: ataufik@bundamulia.ac.id 


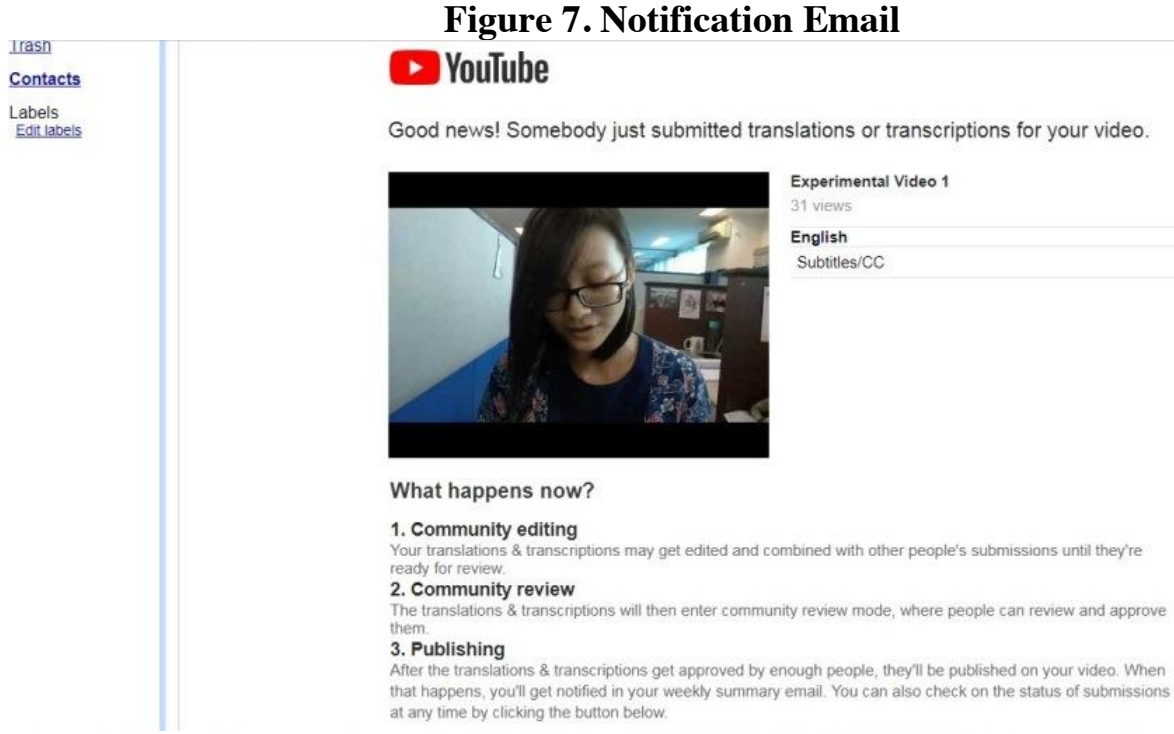

The students are then asked to fill in the questionnaire to share their experience in using the technology in their learning activities. The following is the result of said questionnaire.

Table 2. Adapted TIQ Result 1

The Question: Please indicate how often you use Youtube in your learning activities.

\begin{tabular}{|l|l|l|l|l|l|l|l|}
\hline No. & Respondents & $\begin{array}{l}\text { Not } \\
\text { at all }\end{array}$ & Frequently & Rarely & $\begin{array}{l}\text { Almost } \\
\text { Always }\end{array}$ & Occasionally & $\begin{array}{l}\text { All } \\
\text { the } \\
\text { time }\end{array}$ \\
\hline 1 & R1 & & & 1 & & & \\
\hline 2 & R2 & & & 1 & & & \\
\hline 3 & R3 & & & & 1 & & \\
\hline 4 & R4 & & & 1 & & & \\
\hline 5 & R5 & & & & & 1 & \\
\hline 6 & R6 & & & & 1 & & \\
\hline 7 & R7 & & & 1 & & & \\
\hline 8 & R8 & & & & & 1 & \\
\hline 9 & R9 & & & 1 & & & \\
\hline 10 & R10 & & & 1 & & & \\
\hline & & & & $60 \%$ & $20 \%$ & $20 \%$ & \\
\hline
\end{tabular}

As can be seen from table 2, the respondents rarely use Youtube in their language learning activities. Further results on the background of the students are seen in table 3 .

*Author(s) Correspondence:

E-mail: ataufik@bundamulia.ac.id 
Table 3. Adapted TIQ Result 2

The Question: On average, how many hours per week do you spend using Youtube for personal use outside of learning activities?

\begin{tabular}{|c|c|c|c|c|c|c|c|c|}
\hline No. & Respondents & None & $<2$ hours & $2<x<4$ & $4<x<6$ & $6<x<8$ & $8<x<10$ & $10<$ \\
\hline 1 & R1 & & & 1 & & & & \\
\hline 2 & R2 & & & & & 1 & & \\
\hline 3 & R3 & & & & 1 & & & \\
\hline 4 & R4 & & & & & & 1 & \\
\hline 5 & R5 & 1 & & & & & & \\
\hline 6 & R6 & & & & 1 & & & \\
\hline 7 & R7 & & & & 1 & & & \\
\hline 8 & $\mathrm{R} 8$ & & & & 1 & & & \\
\hline 9 & R9 & & & & & & & 1 \\
\hline $0^{1}$ & R10 & & & & & & & 1 \\
\hline $1^{1}$ & R11 & & & & & & & \\
\hline $2^{1}$ & $\mathrm{R} 12$ & & & & & & & \\
\hline
\end{tabular}

From table 3, the result of the number of hours-per-week of the students using Youtube for other purposes is vary. However, it can be assume that most of them use Youtube more than 4 hours a week. This can be interpreted as a potential learning opportunities for the students, and for the teachers to exploit. The next background question asks them about their status as Youtube users. Here are the results.

Table 4. Adapted TIQ Result 3

The Question: The following descriptions of the proficiency levels a user has in relation to Youtube.

Determine the level that best describes you and circle the corresponding letter on your answer sheet.

\begin{tabular}{|c|c|c|c|c|c|c|c|}
\hline No. & Respondents & Unfamiliar & Newcomer & Beginner & Average & Advanced & Expert \\
\hline 1 & $\mathrm{R} 1$ & & & & 1 & & \\
\hline 2 & $\mathrm{R} 2$ & & & & 1 & & \\
\hline 3 & R3 & & & & 1 & & \\
\hline 4 & $\mathrm{R} 4$ & & 1 & & & & \\
\hline 5 & $\mathrm{R} 5$ & & & 1 & & & \\
\hline 6 & R6 & & & & 1 & & \\
\hline 7 & $\mathrm{R} 7$ & & & 1 & & & \\
\hline 8 & $\mathrm{R} 8$ & & & & 1 & & \\
\hline 9 & R9 & & & 1 & & & \\
\hline 10 & $\mathrm{R} 10$ & & & & & 1 & \\
\hline 11 & R11 & & & & & & \\
\hline 12 & $\mathrm{R} 12$ & & & & & & \\
\hline
\end{tabular}

*Author(s) Correspondence:

E-mail: ataufik@bundamulia.ac.id 
As can be seen from table 4, although most of them spend more than 4 hours a week, they claim to stil be beginner to average users. There is a suspicion that central tendency is in play in this part. Further analysis needs to be conducted. Finally, the following is the result of the students' perception in using Youtube in their actual language learning in the classroom.

Table 5. Adapted TIQ Result 3

\begin{tabular}{|c|c|c|c|c|c|c|c|c|c|c|c|c|c|}
\hline No. & Section/Question & A & $\%$ & B & $\%$ & $\mathrm{C}$ & $\%$ & D & $\%$ & $\mathrm{E}$ & $\%$ & $\mathrm{~F}$ & $\%$ \\
\hline 1 & S2Q1 & & & & & & & $\mathrm{R} 3,4,5,8,9,10$ & $60 \%$ & $\mathrm{R} 1,2,6,7$ & $40 \%$ & & \\
\hline 2 & S2Q2 & $\mathrm{R} 2,6$ & $20 \%$ & R4 & $10 \%$ & & & $\mathrm{R} 1,5$ & $20 \%$ & R3,7,8,9,10 & $50 \%$ & & \\
\hline 3 & $\mathrm{~S} 2 \mathrm{Q} 3$ & & & & & R6,7 & $20 \%$ & R1 & $10 \%$ & $\mathrm{R} 2,3,4,5,9,10$ & $60 \%$ & R8 & $10 \%$ \\
\hline 4 & S2Q4 & & & & & & & R5 & $10 \%$ & $\mathrm{R} 1,2,4,6,7,9$ & $60 \%$ & $\mathrm{R} 3,8,10$ & $30 \%$ \\
\hline 5 & S2Q5 & $\mathrm{R} 2,10$ & $20 \%$ & $\mathrm{R} 4,7,8,9$ & $40 \%$ & R3 & $10 \%$ & & & R1 & $10 \%$ & $\mathrm{R} 5,6$ & $20 \%$ \\
\hline 6 & S2Q6 & & & $\mathrm{R} 2,9$ & $20 \%$ & $\mathrm{R} 10$ & $10 \%$ & & & $\mathrm{R} 4$ & $10 \%$ & $\mathrm{R} 1,3,5,6,7,8$ & $60 \%$ \\
\hline 7 & S2Q7 & R10 & $10 \%$ & $\mathrm{R} 2,6$ & $20 \%$ & R8 & $10 \%$ & $\mathrm{R} 3,7,9$ & $30 \%$ & $\mathrm{R} 1,4,5$ & $30 \%$ & & \\
\hline 8 & S2Q8 & $\mathrm{R} 2,10$ & $20 \%$ & & & $\mathrm{R} 3,6$ & $20 \%$ & $\mathrm{R} 5,7,9$ & $30 \%$ & $\mathrm{R} 4,8$ & $20 \%$ & R1 & $10 \%$ \\
\hline 9 & S2Q9 & & & R4 & $10 \%$ & $\mathrm{R} 1,8$ & $20 \%$ & R5 & $10 \%$ & R6 & $10 \%$ & $\mathrm{R} 2,3,7,9,10$ & $50 \%$ \\
\hline 10 & S2Q10 & $\mathrm{R} 2,7$ & $20 \%$ & R3,5,6 & $30 \%$ & R1,4,9,10 & $40 \%$ & R8 & $10 \%$ & & & & \\
\hline 11 & S2Q11 & & & & & R3 & $10 \%$ & $\mathrm{R} 1,4,5,6,7$ & $50 \%$ & $\mathrm{R} 8,9,10$ & $30 \%$ & R2 & $10 \%$ \\
\hline 12 & S2Q12 & & & & & & & $\mathrm{R} 1,5,7$ & $30 \%$ & R3,4,6,9,10 & $50 \%$ & $\mathrm{R} 2,8$ & $20 \%$ \\
\hline 13 & S2Q13 & & & & & & & $\mathrm{R} 5,8$ & $20 \%$ & $\mathrm{R} 1,2,4,6,7,9,10$ & $70 \%$ & $\mathrm{R} 3$ & $10 \%$ \\
\hline 14 & S2Q14 & $\mathrm{R} 3,10$ & $20 \%$ & $\mathrm{R} 2,9$ & $20 \%$ & $\mathrm{R} 6,7$ & $20 \%$ & $\mathrm{R} 1,8$ & $20 \%$ & $\mathrm{R} 4,5$ & $20 \%$ & & \\
\hline 15 & S2Q15 & & & & & R7 & $10 \%$ & $\mathrm{R} 1,3,5,6$ & $40 \%$ & $\mathrm{R} 2,4,10$ & $30 \%$ & $\mathrm{R} 8,9$ & $20 \%$ \\
\hline 16 & S2Q16 & $\mathrm{R} 2,3,8,10$ & $40 \%$ & & & R7 & $10 \%$ & $\mathrm{R} 6,9$ & $20 \%$ & & & $\mathrm{R} 1,4,5$ & $30 \%$ \\
\hline 17 & S2Q17 & & & $\mathrm{R} 2,10$ & $20 \%$ & $\mathrm{R} 3$ & $10 \%$ & $\mathrm{R} 5,7,8,9$ & $40 \%$ & $\mathrm{R} 4,6$ & $20 \%$ & $\mathrm{R} 1$ & $10 \%$ \\
\hline 18 & S2Q18 & & & $\mathrm{R} 3,10$ & $20 \%$ & R8 & $10 \%$ & $\mathrm{R} 2,5,7,9$ & $40 \%$ & R4 & $10 \%$ & $\mathrm{R} 1,6$ & $20 \%$ \\
\hline 19 & S2Q19 & & & $\mathrm{R} 3,4,10$ & $30 \%$ & $\mathrm{R} 6,7,8$ & $30 \%$ & $\mathrm{R} 1,2,9$ & $30 \%$ & R5 & $10 \%$ & & \\
\hline 20 & $\mathrm{~S} 2 \mathrm{Q} 20$ & & & R4 & $10 \%$ & R1 & $10 \%$ & R3,5,6,7,10 & $50 \%$ & $\mathrm{R} 8,9$ & $20 \%$ & R2 & $10 \%$ \\
\hline
\end{tabular}

In this part, the researcher will observe the frequency per question.

Q1: The use of Youtube increases achievement (e.g.grades).

In this question, $60 \%$ said that they agree slightly while the other moderately agree with the statement/question. This can be interpreted that $60 \%$ of the respondents are still not sure that Youtube uses increase language learning, while the $40 \%$ are quite sure that it does.

Q2: The use of Youtube is effective because I believe I can implement it successfully.

For this question, the answers vary. 20\% strongly disagree, $10 \%$ moderately disagree, $20 \%$ slightly agree, and $50 \%$ moderately agree. There are two implication which can be taken from this. One is about the effectiveness and the other is about the implementation. This can be interpreted that $30 \%$ of the respondents are very and quite sure that the use of Youtube is not effective and unimplementable, $10 \%$ are unsure whether it is effective and implementable, and $50 \%$ are sure that it is effective and implementable.

Q3: The use of Youtube promotes collaboration.

For this question, $20 \%$ said they slightly disagree, $10 \%$ slightly agree, $60 \%$ moderately agree, and $10 \%$ strongly agree. This means that $30 \%$ of the respondents are still unsure whether they promote collaboration, $60 \%$ are quite sure it did, and $10 \%$ are very sure that it did.

Q4: Youtube is a valuable learning tool.

In this part, most answers went toward agreeing with $10 \%$ slightly agree, $60 \%$ moderately agree, and 30\% strongly agree. This is interpreted into only a small portion are unsure about Youtube as a valuable learning tool, and $90 \%$ are quite to very sure that it is.

Q5: Using Youtube is too costly in terms of resources, time and effort

In this, we can see another varied answers. $20 \%$ strongly disagree, $40 \%$ moderately disagree, $10 \%$ slightly disagree, $10 \%$ moderately agree and $20 \%$

*Author(s) Correspondence:

E-mail: ataufik@bundamulia.ac.id 
strongly agree. In its interpretation, this would mean that $60 \%$ of the respondents are very and quite sure that Youtube is not too costly, and it does not waste time and effort. However, $30 \%$ are quite to very sure that it is and did.

Q6: Using Youtube for language learning is successful only if users have access to internet at home.

For this question, 20\% moderatley disagree, $10 \%$ slightly disagree, $10 \%$ moderately agree, and $60 \%$ strongly agree. This means that only $20 \%$ think that it can be used effectively in the classroom, and $70 \%$ are quite to very sure that it was not effective if it was done in the classroom.

Q7: Using Youtube is successful only if there is adequate training in the uses of the technology for learning.

This question is basically about prior training on the use of Youtube for language learning. Another varied answers can be seen here. 10\% strongly disagree, $20 \%$ moderately disagree, $10 \%$ slightly disagree, $30 \%$ slightly agree, and $30 \%$ moderatley agree. This means that $30 \%$ are quite to very sure that training will not aid to the success of using Youtube in the classroom. $40 \%$ are unsure that it will or will not do, and $30 \%$ are quite sure that it will.

Q8: It demands that too much time be spent on technical problems.

This question is focused on the technicalities of the program. $20 \%$ of the respondents for this question strongly disagree, $20 \%$ slightly disagree, $30 \%$ slightly agree, $20 \%$ moderately agree, and $10 \%$ strongly agree. This can be interpreted that $20 \%$ are veru sure that the technicalities of the program takes too much time to use, $50 \%$ are unsure whether they are having problems with the technicalities, and $30 \%$ are quite to very sure that it is too demanding in terms of technicalities.

Q9: Youtube is an effective tool for students of all abilities.

\footnotetext{
*Author(s) Correspondence:

E-mail: ataufik@bundamulia.ac.id
}

This question focuses on the students' abiities. This is related to question number three (3) from the background of the respondents. From this, 10\% moderately disagree, $20 \%$ slightly disagree, $10 \%$ slightly agree, $10 \%$ moderately agree, and $50 \%$ strongly agree. This means that only $10 \%$ belive that this technology is not for everybody. $30 \%$ are unsure whether this technology is available for students of any abilities, and $60 \%$ are quite to very sure that any students with any level of technology proficiency will be able to use this technology.

Q10: Youtube is unnecessary because you will learn computer skills on their own, outside of school.

This question is on whether Youtube should be used in the classroom. From this, $20 \%$ strongly disagree, $30 \%$ moderatley disagree, $40 \%$ slightly disagree, and $10 \%$ slightly agree. This can be interpreted that $50 \%$ of the repondents found it to be quite and very necessary to use Youtube in the classroom, and 50\% are unsure whether Youtube should be or should not be used in the classroom.

\section{Q11: Using Youtube enhances my professional development}

This question is related to the purpose of the use of technology in the classroom, especially Youtube. The answer to this questions states that $10 \%$ slightly disagree, $50 \%$ slightly agree, $30 \%$ moderatley agree, and $10 \%$ strongly agree. This means that $60 \%$ are unsure whether it enhances their professional development, and $40 \%$ are quite to very sure that it does.

Q12: Using Youtube accommodates your personal learning styles.

This question is related to whether the use of Youtube is applicable for students of all learning style. The answers said that $30 \%$ slightly agree, $50 \%$ moderately agree, and $20 \%$ strongly agree. This means that only $30 \%$ are unsure whether it can be adapted to all learning style, and $70 \%$ are quite to very sure that it can be 
adapted to students with any learning style.

Q13: Youtube motivates you to get more involved in learning activities.

This question is related to the students' motivation. It shows that $20 \%$ slightly agree, $70 \%$ moderatley agree, and 10\% strongly agree. This can be interpreted that $20 \%$ of the respondents are unsure whether it motivates them in learning, while $80 \%$ are quite to very sure that it does.

Q14: Using Youtube in the classroom requires software-skills training that is too time consuming.

The answers to this question show that a very balanced distribution. $20 \%$ of the respondents strongly disagree, moderately disagree, slightly disagree, slightly agree, and moderately agree to this. This shows that $40 \%$ are quite to very sure that it does not require software skills training. $40 \%$ are unsure, and $20 \%$ are quite sure that it does.

Q15: It promotes the development of your interpersonal skills.

The answers to this question show $10 \%$ slightly diagree, $40 \%$ slightly agree, $30 \%$ moderately agree, and $20 \%$ strongly agree. This means that $50 \%$ are unsure whether it develops their interpersonal skills, while the other $50 \%$ are quite to very sure that it does.

Q16: Using Youtube in the classroom will increase the amount of stress and anxiety you experience.

The answer to this shows that $40 \%$ strongly disagree, $10 \%$ slightly disagree, $20 \%$ slightly agree, and $30 \%$ strongly agree. This means that $40 \%$ of the respondents did not think that the use of Youtube increased their level of stress and anxiety, $30 \%$ are unsure, and $30 \%$ are very sure that it did.

Q17: The use of Youtube is effective only when extensive computer resources are available
For this question, the answers said that $20 \%$ moderately disagree, $10 \%$ slightly disagree, $40 \%$ slightly agree, $20 \%$ moderately agree, and $10 \%$ strongly agree. This means that $20 \%$ of the respondents are quite sure that you don't need plenty of computer resources to effcetively use Youtube in the classroom. $50 \%$ are unsure that you do or don't, and $30 \%$ are quite to very sure that you do.

Q18: Youtube learning is only successful if computer technology is part of the your home environment.

For this question, 20\% moderatley disagree, $10 \%$ slightly disagree, $40 \%$ slightly agree, $20 \%$ moderately agree, and $10 \%$ strongly agree. This shows that $20 \%$ of the respondents are quite certain that Youtube learning will be successful no matter what your home environment is. $50 \%$ are unsure that it will or will not, and $30 \%$ are quite to very sure that home environment support learning environment.

Q19: The use of Youtube in the classroom requires extra time to plan.

For this question, it shows that $30 \%$ moderately disagree, $30 \%$ slightly disagree, $30 \%$ slightly agree, and $10 \%$ moderately agree. This means that $30 \%$ of the respondents are quite sure that their usage of Youtube in language learning didnot need extra planning time. $60 \%$ are unsure that it did, and only $10 \%$ said that they required extra planning.

Q20: The use of Youtube in the classroom improves your learning of critical concepts and ideas.

For this question, $10 \%$ shows moderate disagreement, $10 \%$ slightly disagree, $50 \%$ slightly agree, and $20 \%$ moderately agree, and $10 \%$ strongly agree. This means that $10 \%$ of the respondents didnot think that the use of Youtube technology improves critical thinking. $60 \%$ are unsure if it did or did not, and $30 \%$ are quite to very sure that it did.

\footnotetext{
*Author(s) Correspondence:

E-mail: ataufik@bundamulia.ac.id
} 


\section{CONCLUSION AND SUGGESTIONS}

To conclude the research, let us refer back to the research questions. The first research question requires the investigation on the elements and features of Youtube which have the potential of increasing connectivity, interaction, and collaboration. As can be seen from the discussion in chapter five, the choice to create a community and set up community contribution has the necessary element to improve connectivity and collaboration. It also increase connectivity since the students can be online whenever they wanted to.

The second research question is from the questionnaire. To sum up, the researcher will divide the questionnaire questions into several distinction and eliminate any central tendency which exist in the answer. The first includes questions which are related to the impact of Youtube in the students' language learning. That will invlove questions number $1,3,11,13,15$, and 20. From the questions, we can conclude that the students believe that it increases achievement, promotes collaboration, enhances professional development, motivates them in learning, promotes interpersonal skills, and improves critical thinking.

The second distinction is related to its implementation. This includes the situation which enhances the implementation and the effectiveness of the implementation. This includes questions number $2,6,7,17$, and 18 . From these questions it can be concluded that it is effective and implementable. However, the respondents also said that it was not effective to be done in the classroom. In addition, they also mentioned that there is too much computer resaources needed to conduct this in the classroom. Furthermore, the respondents are also divided equally in terms of training needed to effectively implement this in the classroom. Some said that it does not need training, while others think so.

The third question list is related to the students opinion on implementing the technology for language learning. This will include questions number $4,5,8,9,10,12,14$,
16, and 19. From this list, it can summed up that the students really think that Youtube is a valuable learning tool. In addition, they also thought that it is inexpensive, very accessible for students of any level of technological skills, necessary, adaptable to all learning styles, and unstressful. If there is any bad point from this, it is that they might have to take too much time to deal with the technicalities of the program.

So, it can be assumed that the response of the students toward Youtube usage in language learning is positive. However, it needs to be done solely NOT in the classroom since they think they require times to deal with technicalities and resources to effectively implement it.

The proper suggestion in this research is for the future research. As seen from table 1, there is an area which is still unknown, namely on the extensive uses of automated caption or speech recognition. Unlike Google Translate, which becomes better after extensive uses, as of this moment, to the best knowledge of the researchers, there haven't been any empirical studies on the quality of automated transcription as it gets used more often. It would make a very good topic of research in the future.

\section{REFERENCES}

Bruner, I. (2013). Using language learning resources on Youtube. Presented at The 6th Edition of the International Conference "ICT for Language Learning." Florence, Italy, 2014. Florence: Libreriauniversitaria.it.

Jones, T., \& Cuthrell, K. (2011). YouTube: Educational potentials and pitfalls. Computers in the Schools, 28(1), 75-85. doi: 10.1080/07380569.2011.553149.

Matthews, B., \& Ross, L. (2010). Research methods: A practical guide for the social sciences. Edinburgh: Pearson Education Ltd.

O'Reilly, T. (2005). What Is Web 2.0. Retrieved from http://www.oreilly.com/

*Author(s) Correspondence:

E-mail: ataufik@bundamulia.ac.id 
pub/a/web2/archive/what-is-web20.html?page $=1$.

Prensky, M. (2009). Make those YouTubes! Retrieved from http://www.marcprensky.com/writing/.

Silverman, D. (2006). Interpreting qualitative data (3rd Edition). California \& London: Sage.

Terantino, J. (2011). YouTube for foreign languages: You have to see this video.
Language Learning \& Technology 15(1), 10-16. Retrieved from http://1lt.msu.edu/issues/february2011/e merging.pdf.

Whatman, P. (2017). 4 Platforms to dive into social media video marketing [Blog post]. Retrieved from https://mention.com/blog/social-mediavideo-marketing/.

*Author(s) Correspondence:

E-mail: ataufik@bundamulia.ac.id 